\title{
The Effect of Collaboration on Iranian EFL Learners' Writing Accuracy
}

\author{
Narges Jafari (Corresponding Author) \\ Department of English, Najafabad Branch, Islamic Azad University, Isfahan, Iran \\ Tel: 98-913-129-5045 E-mail: narguess.jafari@gmail.com \\ Dariush Nejad Ansari \\ Department of English, Faculty of Foreign Language, University of Isfahan, Iran \\ Tel : 98-913-126-7329 E-mail: nejadansari@gmail.com
}

Received: December 5, 2011 Accepted: December 16, 2011 Published: April 1, 2012

doi:10.5539/ies.v5n2p125

URL: http://dx.doi.org/10.5539/ies.v5n2p125

\begin{abstract}
This study aims at finding the effect of group work on Iranian EFL learners' writing accuracy. Moreover, the effect of gender on text production has also been investigated. Over a month, sixty Iranian EFL learners were chosen as the participants of this study. They were divided into two groups. The experimental group wrote collaboratively while the control group underwent individual writing tasks. Both groups participated in four essay writing sessions. The participants wrote on the same topics and genre. The results revealed that the students in the collaborative writing group outperformed the students in the control group, hence emphasizing the significant role of collaboration in L2 writing. Regarding gender effect, the data analysis showed the females in the collaborative group outperformed males in the same group proving that gender plays a significant role in Iranian EFL collaborative writing setting. The results have some implications for English writing instructors and learners.
\end{abstract}

Keywords: Second language writing (L2), Argumentative text, Accuracy, T-unit, Collaborative writing, Gender

\section{Introduction}

The ability to write effectively is becoming more significant in today's communication and academic settings and improving the writing ability of the learners which is assuming an important part in L2 language education (Ghoorchaei, Tavakoli, \& Nejad Ansari, 2010). One popular method of writing instructions is the use of group work in which students in groups of two or three write collaboratively in both first (L1) and second (L2) language learning (Adams \& Hamm, 1996; Doughty \& Pica, 1986). Studies in L1 instruction have shown that EFL learners working in pairs are exposed to a variety of different viewpoints which help them to develop critical thinking skill (Adams \& Hamm, 1996; Barnes \& Todd, 1977; Slavin, 1991). Moreover, group work in L2 educational environment has shown that L2 learners obtain many opportunities to use the target language for different functions (Storch, 1999).

The interest toward collaborative writing had begun in the early 70s' through the work of pioneer Kenneth Bruffee who argued that by making students write compositions and fictions in pairs, students produced better texts in comparison to the times they wrote alone (Bruffee, 1973a). The feedback that the learners receive from this new model of writing can be extremely positive since collaborative writing is reflective both of the business world and the academic field in which students study (Bruffee, 1984). Thus, collaborative writing in the learners' writing achievement in the classroom setting can positively improve in paired writing environment (Bruffee, 1981; Gebhardt, 1980, 1981).

There were also evidences of positive effects of interaction during writing task, especially at college level (O'Donnell, Dansereau, Rocklin, Lambiotte, Hythecker \& Larson, 1985). For instance, Clifford (1981) studied college freshman performance in collaborative writing environment contended that students who wrote in groups learned more from each other than those students working individually. Daiute's research (1986, p. 389) confirmed earlier studies that "students who collaborated made significant improvement over students who wrote individually", and that the group work was better than the best work of any members of the group.

When two or more students write together as well as peer instruct each other, they not only decrease the amount of time to deal with various aspects of writing simultaneously but also gain the benefits in information processing 
terms. The help and the guidance that each member of a pair groups receives, give them many options to process information (Yarrow \& Topping, 2001).

Regarding individual versus collaborative pair work, Shi (1998) was concerned with comparing a written text produced collaboratively with another text produced individually by ESL students from three different pre-university writing classes under different conditions including peer-talk previewing discussion, teacher-led previewing discussion, and no discussion. The findings suggest that there was no significance difference among the peer-talk discussion, teacher-led discussion, and no discussion group, the participants in Shi's study produced a wider range of verbs after peer discussion. Moreover, the findings of Shi's study indicated that the teacher-led as well as peer-talk discussions provided scaffolded help for learners to generate varying degrees of vocabulary, to conceptualize their thinking, and to explore their ideas within the given context. Thus, it would be possible to obtain more comparable results about writing performance across different task conditions.

In one of the earliest studies by Storch (1999), which was in the form of small-scale, triad ESL learners from intermediate to advanced L2 proficiency completed three different kinds of grammar-focused exercises including a cloze, a text reconstruction and a short composition. Each type of exercise had also an isomorphic version which was done individually or collaboratively. A comparison between these two kinds of isomorphic versions suggested that collaboration improves the degree of accuracy and has a positive effect on it, but it is subject to change within specific grammatical items. In particular, the findings suggested that cloze and text reconstructions which had been completed collaboratively were more accurate than those completed individually. Furthermore, compositions produced collaboratively not only gained lower scores in terms of complexity but also had a small number of errors and greater amount of error-free clauses.

Also, Franken and Haslett (2002) concentrated on the effect of interactions in L2 writing conditions. As such, they conducted an experiment exploring the effects of interaction on the rhetorical features of summary writing as well as argumentative writing. Twenty-two high school students with various backgrounds took part in the study to investigate whether interaction with a partner led to better quality of text in comparison to the times when they engage in L2 writing individually. In other words, the participants were given 2 options to finish their compositions: write individually or collaboratively. The results depicted that interaction with a peer had specific effects on the texts that the writers produced. The findings also revealed that working individually results in significantly higher mean scores for linguistic accuracy and complexity in a summary writing task. Moreover, the findings implied that interaction with a peer is more effective in argumentative writing tasks where learners are required to have more specific domain knowledge in order to generate ideas and support their ideas as well.

Regarding individual versus collaborative pair work, Storch (2005) studied the effectiveness of collaborative writing on L2 argumentative essays. Her study analyzed both the final product of their writing task (in terms of fluency, accuracy and complexity) as well as the nature of interaction during the task. The results revealed that collaboration among team members leads to many opportunities for idea exchanging and peer feedback. Moreover, the results also indicated that the students who produced the text in pair wrote shorter but grammatically more accurate and more complex texts in comparison to those who produced the texts individually. But the difference between the individual and group work was not statistically significant, suggesting that the reason for this lack of significant might probably have to do with short length of the text and the small sample size, thus there is a need for further research.

Storch (2007) has investigated the benefits of pair work by comparing texts produced by pairs versus those produced by individuals. The study was conducted in four ESL classes. Students in class A completed their task in pairs whereas student in class B completed their task individually. Both class C and Class D had to choose from either of these two conditions (e.g. working individually or collaboratively). All the gathered data had been audiotaped and transcribed for further investigation. Careful analysis of edited texts showed that there was no significant difference in terms of accuracy of tasks completed individually or collaboratively, also analysis of transcribed paired revealed that most pairs engage actively in the word choice. Thus the finding suggested that although group work on grammatical task may not lead to greater levels of accuracy, but it provides L2 learners the opportunity to use L2 language and to learn the language.

Accordingly, Wiggleworth and Storch (2009) conducted a study to investigate the advantages of paired writing in second language contexts among 48 pair writing groups in a number of measures. They compared and contrasted the writing scripts produced by learners working in pairs with those of learners working individually in number of measures like accuracy, fluency and complexity of the texts produced. Participants were also asked to write an argumentative essay in which they should debate the advantages and disadvantages of exam-based assessment. Therefore, 48 pairs of students as well as 48 individuals completed the writing tasks. Results revealed that collaboration had a positive effect on accuracy, but does not affect fluency or complexity. 
Leki (2001) investigated the effect of collaboration in L2 writing. The results revealed that although group work had to be encouraged, but it was not always a positive learning experience for learners. Strauss and U (2007) clearly stated that group work provided lots of learning opportunities for learners such as helping them to express their ideas freely and vividly when they have difficulty to express themselves appropriately in English. Additionally, Mutch (1998) believed that the increased interest toward group work lead not only to improvement in learners' accountability, but it is also a medium of reducing pressure on academic educational environment. Although pair writing is a new phenomenon in foreign/ second language instruction, the impact of such technique on L2 writing improvement is to some extent unclear since there are controversial results gained from different researchers in second language learning

Following the above mentioned lines of research, the present study tries to shed some light on the effect of Iranian EFL pair works on the textual accuracy of the writing task and addressed the following research questions:

1) Does collaborative writing improve Iranian EFL learners' writing achievement in terms of accuracy?

2) Does gender play any significant roles in the writing achievement of Iranian EFL learners' collaborative groups?

Based on the above questions, the following hypotheses were formulated:

1) Collaboration in writing does not have any significant effects on the accuracy of Iranian EFL learners' writing achievement.

2) Gender does not play any significant roles in the writing achievement of Iranian EFL learners' collaborative writing groups.

\section{Method}

\subsection{Participants}

The participants of this study were selected from among Iranian EFL students at Sobh-e-Sadegh University in Isfahan, Iran. They consisted of 30 male and 30 female learners. The participants were members of the two essay writing classes, both of which were taught by the same instructor.They were between 20 and 27 years old. The learners' EFL proficiency based on the placement test showed that they were all at the intermediate level of proficiency.

\subsection{Instruments}

The instrument used in this study included Solution Placement Test as well as some writing tasks. The placement test was developed by Lynda Edwards (2007). It consists of 50 multiple-choice items with optional reading and writing sections. The allotted time for testing is about 45 minutes, with further 20 minutes for writing. The argumentative writing topics were selected from the internet site " 40 writing topics for argument and persuasion". The main criterion for topic selection was learners' familiarity with the topics as well as their eagerness to generate ideas based on the assigned topics.

\subsection{Procedure}

The study required that selected EFL learners both in experimental and control groups, attended four successive writing sessions. The class met once in a week for two hours during which EFL learners had some essay writing tasks on argumentative topics that were taken from the Internet site " 40 writing topics: argument and persuasion" by Nordquist (n. d.).

This genre was chosen by the researcher in order that the participants analyze the topics logically and improve their reasoning power. The primary basis for topic selection was students' familiarity as well as interest toward the topics. The instructor used the textbook A Complete Guide to Academic Writing for EFL Learners by Rahimi and Mehrpour (2010) to exemplify the argumentative texts as well as writing rules and conventions. The EFL learners did not have the permission to use any reference books especially dictionaries during writing essays. The teachers' job was to provide every written text with corrective feedback as well as some suggestions in written form to improve the participants writing achievement.

In the first session, following the placement test, EFL students became informed about the mechanics of argumentative writing and some sample texts provided by the teacher as most learners did not have any clues about this particular type of writing.

In the control group, sixty participants engaged in the task of individual writing without any collaborative activities and the interaction was mainly between the instructor and students. The assigned topics in both groups were the same and the instructor used the same procedure for providing feedback to students' essays written in the classroom. 
In the next two successive practice sessions, students in the experimental group were asked to write about the given topics in pairs. The argumentative topics for these two practice writing sessions were as follows:

1) Romantic love is a poor basis for marriage. Agree/ disagree. Give your reasons with specific examples.

2) Students should not be required to take physical education courses. Agree/ disagree. Give your reasons with specific examples.

In the experimental groups, sixty EFL learners completed the given argumentative writing task by the joint collaboration of their team members (e.g. self-selection of their partner), as the number of students in both male and female collaborative groups was uneven, there were 6 dyads as well as 1 triad groups for both male and female groups. Each group was required to write one essay collaboratively.

The teacher also walked between the groups, answered students' questions as well as provided support when needed. Also, the instructor provided EFL students with some possible suggestions to make group work a successful and enjoyable activity as follows:

1) Clearly explaining to students what collaboration is.

2) Structuring the collaborative act carefully.

3) Monitoring the pairs.

4) Setting time limits for task completion

5) Asking the pairs to report their experience of collaboration.

The purpose of these practice sessions was to promote pair work among EFL learners who barely had any professional academic experiences working together. Thus, in every writing session students were required to engage actively through the writing task within the regular time constraint of the classroom provided by the instructor. The written texts were gathered and corrected manually based on the correction scheme adapted from Storch and Wigglesworth (2009), by computing the number of clauses, T-units, as well as Error-Free clauses and Error-Free T-units. Moreover, another English MA student who had enough experience in teaching writing corrected the students' essays in order to arrive at more accurate answers regarding the exact number of clauses, T-units, Error-Free clauses, and Error-Free T-units.

In the last session, the post-test that was another argumentative topic (i.e. the primary mission of universities must be preparing students for the workforce. Agree/ disagree. Give your reasons with specific examples) was given to all control and experimental group members to write individually under the usual time of the classroom. Like the two practice sessions, the instructor gathered and corrected students' written essays.

\section{Results}

Since there were only two groups involved in this study, a T-test was used to determine if there was any statistically significant difference between the mean score of the experimental and control group.

As it is indicated in Table (1), the amount of p-value for both measures of accuracy is $<.05$, thus we assume that there is a significant difference between the performances of the two groups and as such the first hypothesis is rejected. That is, collaborative writing can have a significant effect on the performance of Iranian EFL learners.

In order to answer research question (2), another T-test was performed to investigate the presumed effect of gender on collaboration writing in terms of accuracy (refer to Table 2).

As it is indicated in Table (2), since the amount of p-values for both measures of accuracy are lower than .05, there is a significant difference between measures of accuracy for female pairs. As such, it is safe to say that females in the collaborative group outperform males indicating that gender makes a distinction toward the quality of the text.

\section{Discussion}

The purpose of this study was to investigate the effect of pair work on textual accuracy. The results of the data analysis revealed that when learners worked collaboratively on the same argumentative writing task, they produced more T-units as well as more Error-Free T-units in comparison to the times when they were working individually. As it is taken from other earlier studies (Donato, 1994), when a group of learners working together to accomplish a task, they use team members' morphological knowledge and as such they produce more accurate text. The first result illustrates why learners in the experimental group managed to produced more accurate texts than the learners in the individual group. It sounds that the process of collaboration and working together among group members toward the same goal has played a significant role in the overall performance of the learners who attempted the task collaboratively. 
Additionally, the improved accuracy observed among collaborative writing groups may be due to increased motivation to focus on grammatical accuracy. Another reason is that each learner in collaborative groups engaged in revision process and as such learners were engaged in the multi-revision process which actually led to more accurate texts.

Moreover, as it is clear from Table (2), the effect of gender has also been discussed. It is revealed that there is a significant difference between female participants since the p-values for both measures of accuracy are lower than .05 and as such the researcher can assume that female participant (e.g. individual as well as collaborative groups) produces more accurate T-units and clauses.

\section{Implications}

The implications of this study can have some theoretical and practical implications. As for the theoretical aspect, this study can provide some hints for those researchers who are interested in developing a comprehensive model for L2 writing process. Considering the practical implications, in nearly all writing classes teachers feel responsible to provide corrective feedback to all individual student writings, collaborative writing can be beneficial for teachers in the sense that collaboration among students can result in more accurate texts as learners receive feedback from each other not just from their teacher. Students also benefit from the results of this study as collaborative writing gives them a sense of accountability for their group members improvement.

\section{References}

Adam, D. M., \& Hamms, M. (1996). Cooperative Learning, Critical Thinking and Collaboration across the Curriculum. Springfield, IL: Charles Thomas.

Barnes, D., \& Todd, F. (1977). Communication and Learning in Small Groups. London: Routled and Kegan Paul.

Bruffee, K. A. (1973). Collaborative Learning: Some Practical Models. College English. 34, 634-643. http://dx. doi.org/ 10.2307/375331

Bruffee, K.A. (1981). Collaborative Learning. College English. 43(7), 745-747. http://dx. doi.org/10.2307/376907

Bruffee, K.A. (1984). Collaborative Learning and the Conversation of Mankind. College English. 46, 635-652. http://dx.doi.org/10.2307/376924

Clifford, J. (1981). "Comparing in Stages: The Effects of a Collaborative Pedagogy." Research in the Teaching of English. 15, 37-53.

Diatue, C. (1986). "Do 1 and 1 make 2? Patterns of Influence by Collaborative Authors." Written Communication. 3(3), 383-408.

Donato, R. (1994). Collective scaffolding in second language learning. In J. P. Lantolf, \& G. Appel (Eds.). Vygotskian approaches to second language research (pp.33-56). Norwood, NJ: Ablex.

Doughty, C., \& Pica, T. (1986). Information Gap Tasks: Do they Faciliate Second Language Acquisition? TESOL Quarterly. 20, 305-325. http://dx.doi.org/10.2307/3586546

Edward, L. (2007). Solution Placement Test. Oxford: Oxford University Press.

Franken, M., \& Haslett, S. (2002). When and Why Talking Can Make Writing Harder. In S. Ransdell, \& M. L. Barbier (Eds.). New Directions for Research in L2 Writing (pp. 208-229). Dordrecht, the Netherlands: Kluwer Academic. http://dx.doi.org/10.1007/978-94-010-0363-6_11

Gebhardt, R. (1980). Teamwork and Feedback: Broadening the Base of Collaborative Writing. College English, 42(1), 69-74. http://dx.doi.org/10.2307/376038

Gebhardt, R. (1981). Richard Gebhardt Responds. College English. 43(7), 747-749. http://dx.doi.org/10.2307/ 376908

Ghoorchaei, B., Tavakoli, M., \& Nejad Ansari, D. (2010). The Impact of Portfolio Assessment on Iranian EFL Students' Essay Writing: A Process-oriented Approach. GEMA online Journal of Language Studies. 10(3), 35-51.

Leki, I. (2001). 'A narrow thinking system': Nonnative-English-speaking students in group projects across the curriculum. TESOL Quarterly. 53 (1), 39-67. http://dx.doi.org/10.2307/3587859

Mutch, A. (1998). Employability or Learning? Group Work in Higher Education. Education and Training. 40 (2), 50-56. http://dx.doi.org/10.1108/00400919810206884

Nordquist, N. (n. d.). 40 Writing Topics: Argument \& Persuasion. [Online] Available: http://grammar.about. com/od/developingessays/a/topicargumt07.htm (December, 2011) 
O’ Donnell, A. M., Dansereau, D. F., Rockin, T., Lambiotte, J. C., Hythecker, V. I., \& Larson, C. O. (1985). Cooperative Learning: Direct Effects and Transfer. Written Communication, 2(3), 307-315.

Rahimi, M., \& Mehrpour, S. (2010). A Complete Guide to Academic Writing for EFL Learners. Shiraz: Shiraz University Press. (Chapter 8).

Shi, L. (1998). Effects of Pre-writing Discussions on Adult ESL Students' Compositions. Journal of Second Language Writing. 7(3), 319-345. http://dx.doi.org/10.1016/S1060-3743(98)90020-0

Slavin, R. E. (1991). Cooperative Learning: Theory, Research and Practice. Englewood Cliffs, NJ: Prentice- Hall.

Storch, N. (1999). 'Are two heads better than one?’ Pair Work and Grammatical Accuracy'. Systems. 27 (3), $363-374$. http://dx.doi.org/10.1016/S0346-251X(99)00031-7

Storch, N. (2005). 'Collaborative Writing: Product, Process and Students' Reflections'. Journal for Second Language Writing, 14 (3), 153-173. http://dx.doi.org/10.1016/j.jslw .2005.05.002

Storch, N. (2007). Investigating the Merits of Pair Work on a Text Editing Task in ESL Classes. Language Teaching Research, 11, 143-159. http://dx.doi.org/10.1177/1362168807074600

Storch, N., \& Wiggleworth, G. (2009). Pair versus Individual Writing: Effects on Fluency, Complexity and Accuracy. Language Testing, 26(3), 445-466. http://dx.doi.org/10.1177/0265532209104670

Strauss, P., \& U, A. (2007). Group Assessments: Dilemma Facing Lecturer in Multicultural Classrooms. Higher Education Research and Development. 26(2), 147-161. http://dx.doi.org/10.1080/07294360701310789

Yarrow, F., \& Topping, K. J. (2001). Collaborative Writing: The Effects of Metacognitive Prompting and Structured Peer Interaction. British Journal of Educational Psychology, 71, 261-282. http://dx. doi.org/10.1348/ 000709901158514PMid:11449936

Table 1. The Result of T-test for Accuracy

\begin{tabular}{|c|c|c|c|c|c|c|c|c|c|c|}
\hline & & \multicolumn{2}{|c|}{$\begin{array}{l}\text { Levene's Test } \\
\text { for Equality } \\
\text { of Variances }\end{array}$} & \multicolumn{7}{|c|}{ T-test for Equality of Means } \\
\hline & & \multirow[t]{2}{*}{$\mathrm{F}$} & \multirow[t]{2}{*}{ Sig. } & \multirow[t]{2}{*}{$\mathrm{T}$} & \multirow[t]{2}{*}{ Df } & \multirow[t]{2}{*}{$\begin{array}{c}\text { Sig. } \\
\text { (2-tailed) }\end{array}$} & \multirow[t]{2}{*}{$\begin{array}{c}\text { Mean } \\
\text { Difference }\end{array}$} & \multirow[t]{2}{*}{$\begin{array}{l}\text { Std. Error } \\
\text { Difference }\end{array}$} & \multicolumn{2}{|c|}{$\begin{array}{l}95 \% \text { Confidence } \\
\text { Interval of the } \\
\text { Difference }\end{array}$} \\
\hline & & & & & & & & & Lower & Upper \\
\hline \multirow{2}{*}{$\begin{array}{l}\text { Error-free } \\
\text { T-units to } \\
\text { T-units }\end{array}$} & $\begin{array}{l}\text { Equal variances } \\
\text { assumed }\end{array}$ & 1.234 & .271 & -2.898 & 58 & .005 & -.12053 & .04159 & -.20378 & -.03729 \\
\hline & $\begin{array}{l}\text { Equal variances } \\
\text { not assumed }\end{array}$ & & & -2.898 & 55.679 & .005 & -.12053 & .04159 & -.20386 & -.03721 \\
\hline \multirow{2}{*}{$\begin{array}{l}\text { Error-free } \\
\text { Clause to } \\
\text { Clause }\end{array}$} & $\begin{array}{l}\text { Equal variances } \\
\text { assumed }\end{array}$ & 4.849 & .032 & 2.883 & 58 & .006 & .13213 & .04582 & .04040 & .22385 \\
\hline & $\begin{array}{l}\text { Equal variances } \\
\text { not assumed }\end{array}$ & & & 2.883 & 51.073 & .006 & .13213 & .04582 & .04014 & .22412 \\
\hline
\end{tabular}


Table 2. The Result of T-Test for Accuracy across Gender

\begin{tabular}{|c|c|c|c|c|c|c|c|c|c|c|c|}
\hline \multirow{3}{*}{\multicolumn{3}{|c|}{ Gender }} & \multicolumn{2}{|c|}{$\begin{array}{c}\text { Levene's } \\
\text { Test for } \\
\text { Equality of } \\
\text { Variances }\end{array}$} & \multicolumn{7}{|c|}{ T-test for Equality of Means } \\
\hline & & & \multirow[t]{2}{*}{$\mathrm{F}$} & \multirow[t]{2}{*}{ Sig. } & \multirow[t]{2}{*}{$\mathrm{T}$} & \multirow[t]{2}{*}{ Df } & \multirow[t]{2}{*}{$\begin{array}{l}\text { Sig. } \\
\text { (2-tail } \\
\text { ed) }\end{array}$} & \multirow[t]{2}{*}{$\begin{array}{c}\text { Mean } \\
\text { Difference }\end{array}$} & \multirow[t]{2}{*}{$\begin{array}{l}\text { Std. Error } \\
\text { Difference }\end{array}$} & \multicolumn{2}{|c|}{$\begin{array}{l}95 \% \text { Confidence } \\
\text { Interval of the } \\
\text { Difference }\end{array}$} \\
\hline & & & & & & & & & & Lower & Upper \\
\hline \multirow[t]{4}{*}{ Female } & \multirow[t]{2}{*}{$\begin{array}{l}\text { Error-free } \\
\text { T-units to } \\
\text { T-units }\end{array}$} & $\begin{array}{l}\text { Equal } \\
\text { variances } \\
\text { assumed }\end{array}$ & .006 & .937 & -2.149 & 28 & .040 & -.13468 & .06267 & -.26305 & -.00631 \\
\hline & & $\begin{array}{l}\text { Equal } \\
\text { variances } \\
\text { not } \\
\text { assumed }\end{array}$ & & & -2.149 & 27.999 & .040 & -.13468 & .06267 & -.26305 & -.00631 \\
\hline & \multirow[t]{2}{*}{$\begin{array}{l}\text { Error-free } \\
\text { Clause to } \\
\text { Clause }\end{array}$} & $\begin{array}{l}\text { Equal } \\
\text { variances } \\
\text { assumed }\end{array}$ & 2.395 & .133 & 3.152 & 28 & .004 & .21456 & .06808 & .07511 & .35401 \\
\hline & & $\begin{array}{l}\text { Equal } \\
\text { variances } \\
\text { not } \\
\text { assumed }\end{array}$ & & & 3.152 & 23.953 & .004 & .21456 & .06808 & .07404 & .35507 \\
\hline \multirow[t]{4}{*}{ Male } & \multirow[t]{2}{*}{$\begin{array}{l}\text { Error-free } \\
\text { T-units to } \\
\text { T-units }\end{array}$} & $\begin{array}{l}\text { Equal } \\
\text { variances } \\
\text { assumed }\end{array}$ & 2.086 & .160 & -1.876 & 28 & .071 & -.10638 & .05671 & -.22254 & .00978 \\
\hline & & $\begin{array}{l}\text { Equal } \\
\text { variances } \\
\text { not } \\
\text { assumed }\end{array}$ & & & -1.876 & 23.166 & .073 & -.10638 & .05671 & -.22365 & .01088 \\
\hline & \multirow[t]{2}{*}{$\begin{array}{l}\text { Error-free } \\
\text { Clause to } \\
\text { Clause }\end{array}$} & $\begin{array}{l}\text { Equal } \\
\text { variances } \\
\text { assumed }\end{array}$ & 6.363 & .018 & 1.845 & 28 & .076 & .10958 & .05940 & -.01210 & .2312 \\
\hline & & $\begin{array}{l}\text { Equal } \\
\text { variances } \\
\text { not } \\
\text { assumed }\end{array}$ & & & 1.845 & 22.128 & .079 & .10958 & .05940 & -.01357 & .23274 \\
\hline
\end{tabular}

